\title{
Particleboard Panels Produced with Different Radial Positions of Pinus oocarpa Wood
}

\author{
Rafael Farinassi Mendes ${ }^{1}$, Naiara Sena Baleeiro ${ }^{2}$, Lourival Marin Mendes ${ }^{2}$, \\ Mário Vanoli Scatolino ${ }^{2}$, Stefânia Lima Oliveira ${ }^{2}$, Thiago de Paula Protásio ${ }^{2}$ \\ ${ }^{1}$ Departamento de Engenharia, Universidade Federal de Lavras - UFLA, Lavras/MG, Brazil \\ ${ }^{2}$ Departamento de Ciências Florestais, Universidade Federal de Lavras - UFLA, Lavras/MG, Brazil
}

\begin{abstract}
The aim of this study was to evaluate the effect of different radial regions of Pinus oocarpa wood on the physical and mechanical properties of particleboard panels. Three different radial regions (internal, intermediate and external) and the mixture (integral log) were assessed. Experimental panels were produced with a nominal density of $0.70 \mathrm{~g} / \mathrm{cm}^{3}$ using $8 \%$ urea-formaldehyde adhesive; they were compressed at a specific pressure of $40 \mathrm{kgf} / \mathrm{cm}^{2}$ and temperature of $160{ }^{\circ} \mathrm{C}$, for 8 minutes. Wood radial position affected particleboard quality and a direct influence of the chemical composition and density of the material used was observed. Only the panels produced the mixture (integral $\log$ ) and with the internal region met all the requirements stipulated by the marketing standard.
\end{abstract}

Keywords: particleboard, radial regions, physical and mechanical properties. 


\section{INTRODUCTION}

The wood and lumber industry in Brazil generates a large amount of residue. This constitutes a problem for sawmills because only part of the wood residue volume generated can be reused. The residue is mostly used in energy production for the own sawmills, where it is burned in furnaces or craft ovens, or used in farming. However, the value added is still very low in both cases. A possible alternative for the use of residues is the production of particleboard panels, which may be produced from any lignocellulosic material, considering that they present good physical and mechanical properties (Mendes et al., 2010). Some studies have been conducted on the use of wood residues for the production of particleboard panels, obtaining good results with the use of chips and shavings generated by the planning of sapwood and/or heartwood (Dacosta et al., 2005; Cabral et al., 2007), with different sawmill residues (Iwakiri et al., 2000, 2012; Felix et al., 2016) from log rounding process for lamination (Guimarães et al., 2011) and for particleboard production in laboratory scale. Although it is well known that anatomical, physical, chemical and mechanical differences between the regions of a wood $\log$ provide different types of bonding and resistance to particleboards, directly affecting the final quality of panels and their applications, no studies comparing the effects of different wood radial regions on particleboard properties have been conducted to date.

In this context, the aim of this study was to evaluate the effect of different radial regions of Pinus oocarpa wood on the physical and mechanical properties of particleboard panels.

\section{MATERIAL AND METHODS}

\subsection{Material collection}

Four Pinus oocarpa trees aged 30 years were obtained from the campus of the Federal University of Lavras (UFLA), Lavras, Minas Gerais state, Brazil. After felling, the trees were sawn into logs and discs were removed for determination of wood basic density according to NBR 11941 standard (ABNT, 2003a) and for wood chemical analysis. The logs were collected from a position between the base and $25 \%$ of tree height.

\subsection{Chemical analysis of wood}

For analysis of the chemical components, sawdust was obtained from the processing of wood in a Wiley mill. Sawdust that passed through a 40 mesh sieve and was retained on a 60 mesh sieve was used. After storage at a temperature of $22 \pm 2{ }^{\circ} \mathrm{C}$ and relative humidity $(\mathrm{RH})$ of $65 \pm 5 \%$, this material had its total extractive, lignin and ash contents assessed according to NBR 14853 (ABNT, 2010a), NBR 7989 (ABNT, 2010b), and NBR 13999 (ABNT, 2003b) standards, respectively. The holocellulose content was further determined by Equation 1.

$H(\%)=100-\%$ total extractives $-\%$ lignin amount $-\%$ ash

\subsection{Experimental design and particleboard production}

The experimental design is described in Table 1. For each treatment, three particleboard panels with a nominal density of $0.70 \mathrm{~g} / \mathrm{cm}^{3}$ were produced.

Three different radial regions (internal, intermediate and external) and the mixture (integral log) were evaluated, as in the current industrial production of particleboard panels. This definition by region is used because this species does not show evident visual differentiation between heartwood, sapwood, and pith; however, the equivalence of the regions was sought in the present study.

The obtained logs were cooked in a tank containing water at $60^{\circ} \mathrm{C}$ for 24 hours. Subsequently, they were laminated in a rolling mill to obtain veneers with nominal thickness of $2 \mathrm{~mm}$. Three logs were laminated discontinuously in order to separate the regions (internal, intermediate and external). After that, the veneers generated from each log were mixed within each predefined region. One log was laminated continuously for the manufacture of the mixture treatment (T4), with the remainder of the log incorporated into the pruning process for particle generation. The material

Table 1. Experimental design.

\begin{tabular}{cc}
\hline Treatments & Wood radial position \\
\hline T1 & External region \\
T2 & Intermediate region \\
T3 & Internal region \\
T4 & Mixture \\
\hline
\end{tabular}


not used in the production of particleboard panels with only the internal, intermediate or external region was proportionally added to each region, to the material originated from the log that was laminated continuously. The obtained veneers were manually torn and then crushed in a hammer mill using a $6.1 \mathrm{~mm}$ aperture sieve, producing the "sliver" particles. To obtain the internal region particles, the reminder of the log was chopped into chips using a machete, being subsequently crushed in a hammer mill using a sieve of the same previously mentioned aperture. The material was then sieved on a $3 \mathrm{~mm}$-aperture vibrating sieve to eliminate the fine particles; they were then submitted to drying until a moisture content of $3 \%$ was reached. For the production of the panels, urea-formaldehyde adhesive with a viscosity of $1506.73 \mathrm{cP}$, solids content of $56 \%$, gel time of 13.14 minutes, and $\mathrm{pH}$ of 8.91 was used. The adhesive was applied to the particles by aspersion in a rotary drum at a rate of $8 \%$ solids content (dry weight basis). After being pre-pressed in manual press $\left(3 \mathrm{kgf} / \mathrm{cm}^{2}\right)$ at room temperature, the glued particles were deposited on a $48 \times 48 \mathrm{~cm}$ mat-forming box and were then hot pressed at $160{ }^{\circ} \mathrm{C}$ and $40 \mathrm{kgf} / \mathrm{cm}^{2}$ specific pressure, for 8 minutes. Metallic spacers were responsible for determining the final thickness of the panels $(15 \mathrm{~mm})$.

\subsection{Assessment of particleboard properties}

After pressing, the panels were stored in an environmental chamber at $22 \pm 2{ }^{\circ} \mathrm{C}$ and $65 \pm 5 \% \mathrm{RH}$. The samples were prepared using a circular saw. Dimensions of the specimens and test procedures were defined based on the American Society for Testing and Materials - ASTM D 1037 (ASTM, 2006). The following properties and/or parameters were determined: moisture content, water absorption (WA) after two and 24 hours of immersion, thickness swell (TS) after two and 24 hours of immersion, and internal bond
(IB). The Normen Für Holzfaserplaten Spanplatten Sperrholz - DIN 52362 (DIN, 1982) standard was used for assessment of modulus of rupture (MOR) and modulus of elasticity (MOE). The density of the panels was determined by the mean density of the specimens produced for the aforementioned tests.

\subsection{Statistical analysis}

Statistical analyses were conducted in a completely randomized design. The Tukey test was applied for verification of the effect of wood radial position on the physical and mechanical properties of the particleboard panels. A significance level of $5 \%(p<0.05)$ was adopted for all statistical analyses.

\section{RESULTS AND DISCUSSION}

\subsection{Chemical analysis}

It was observed that the evaluated regions showed statistical difference regarding the chemical constitution, which confirms the good separation of the regions within the assessed logs (Table 2).

The internal region showed statistically significant difference in relation to the others as well as to the mixture when the contents of extractives, lignin, and holocellulose were analyzed, presenting the highest mean values for extractives and lignin, and the lowest value for holocellulose. Arantes et al. (2011) evaluated the content range of lignin and extractives in the radial and longitudinal directions of Eucalyptus grandis W.Hill ex Maiden x Eucalyptus urophylla ST Blake trees, at the age six years, and found decreased mean values of lignin and extractives in the pith-bark direction, as observed in this study, from the internal to the external regions. The mixture treatment also showed a statistical difference in relation to the external and

Table 2. Chemical analysis.

\begin{tabular}{ccccc} 
Treatments & Extractives & Lignin & Ash & Holocellulose \\
\cline { 2 - 5 } & & & $\%$ & \\
\hline External region & $5.54(7.04) \mathrm{C}$ & $28.28(1.13) \mathrm{C}$ & $0.26(3.08) \mathrm{B}$ & $65.92(1.01) \mathrm{B}$ \\
Intermediate region & $2.80(1.43) \mathrm{D}$ & $28.16(0.43) \mathrm{C}$ & $0.34(2.94) \mathrm{A}$ & $68.71(0.23) \mathrm{A}$ \\
\hline Internal region & $21.63(6.01) \mathrm{A}$ & $30.65(0.07) \mathrm{A}$ & $0.26(3.85) \mathrm{B}$ & $47.47(2.76) \mathrm{D}$ \\
\hline Mixture & $12.22(4.75) \mathrm{B}$ & $29.03(0.41) \mathrm{B}$ & $0.29(3.45) \mathrm{AB}$ & $58.46(1.16) \mathrm{C}$ \\
\hline
\end{tabular}

Means followed by the same letter in the column do not differ statistically by the Tukey test at $5 \%$ significance level. The values in parentheses correspond to the coefficient of variation. 
intermediate regions when analyzing the amount of extractives, lignin, and holocellulose, presenting the highest mean values for extractives and lignin, and the lowest mean value for holocellulose.

The comparison between the external and intermediate regions showed no statistically significant difference only for the lignin content, whereas the external region presented the highest mean values for extractives. As for the contents of holocellulose and ash, the intermediate region presented the highest mean values. The intermediate region showed the highest mean value for holocellulose, differing statistically from the other regions and from the mixture. Regarding the ash content, the internal region was statistically equal to the mixture and external region, but statistically different from the intermediate region, which presented higher mean value for ash content. Morais et al. (2005) obtained mean values of $80.27 \%$ for holocellulose, $25.18 \%$ for lignin, and $9.95 \%$ for extractives in the evaluation of the chemical composition of Pinus oocarpa wood at the age of eight years.

\subsection{Wood basic density, panel apparent density, compaction ratio, and moisture content}

Statistically significant differences were observed for wood basic density when comparing the different treatments (Table 3). The intermediate region and the mixture were statistically equal, presenting the highest mean values. No statistical difference was observed between the external and internal regions and the mixture. Mean apparent density of the panels ranged from 0.638 to $0.681 \mathrm{~g} / \mathrm{cm}^{3}$, being classified as low density panels, which refer to panels with a density between 0.60 and $0.80 \mathrm{~g} / \mathrm{cm}^{3}$ (ABNT, 2006).

The compaction ratio of the internal region was statistically different from those of the other regions, showing the highest mean value. This may be explained by the lower density of the wood from the internal region, which is mainly composed of pith, whereas the external region and the mixture were not statistically different. The intermediate region presented the lowest mean compaction ratio value, differing from the other regions and from the mixture. Due to the variation in wood basic density of the different regions, only the panels produced with wood from the intermediate region did not show mean compaction ratio values stipulated as ideal by Tsoumis (1991) and Maloney (1993), which are in the range from 1.3 to 1.6.

Statistically significant difference was observed between treatments with respect to the moisture content of the panels. Panels produced with wood from the internal region showed statistically significant lower moisture contents than the other treatments, which in turn were statistically equal. This fact may be explained by the higher amount of extractives in this region (Table 2).

\subsection{Physical properties}

The internal region treatment differed statistically from the other treatments in all physical properties evaluated (Table 4), presenting the lowest mean values. This fact can be explained by the association of two factors: higher compaction ratio (Table 3), which probably promoted a greater barrier to water penetration; and chemical composition of the wood, which showed higher contents of lignin and extractives (Table 2). The high amount of extractives found in the internal region, compared with those of the other regions and the mixture, may exert the function of water repellency on the panels.

No significant difference was observed between the treatments composed of the external and intermediate regions and the mixture for any of the physical properties evaluated. This fact demonstrates the efficiency of

Table 3. Mean values of wood density, panel apparent density, compaction ratio, and moisture content.

\begin{tabular}{|c|c|c|c|c|}
\hline \multirow{2}{*}{ Treatment } & Wood density & Panel density & \multirow{2}{*}{ Compaction ratio } & \multirow{2}{*}{$\begin{array}{c}\text { Moisture } \\
(\%)\end{array}$} \\
\hline & \multicolumn{2}{|c|}{$\mathrm{g} / \mathrm{cm}^{3}$} & & \\
\hline External region & $0.448(5.2) \mathrm{B}$ & $0.638(1.65) \mathrm{A}$ & $1.42(1.6) \mathrm{B}$ & $10.23(3.3) \mathrm{B}$ \\
\hline Intermediate region & $0.559(4.4) \mathrm{A}$ & $0.640(4.77) \mathrm{A}$ & $1.14(4.8) \mathrm{C}$ & $10.27(2.0) \mathrm{B}$ \\
\hline Internal region & $0.431(6.8) \mathrm{B}$ & $0.681(4.37) \mathrm{A}$ & $1.58(3.8) \mathrm{A}$ & $8.22(2.3) \mathrm{A}$ \\
\hline Mixture & $0.479(6.5) \mathrm{AB}$ & $0.654(3.16) \mathrm{A}$ & $1.37(3.2) \mathrm{B}$ & $10.17(0.30) \mathrm{B}$ \\
\hline
\end{tabular}

Means followed by the same letter in the column do not differ statistically by the Tukey test at $5 \%$ significance level. The values in parentheses correspond to the coefficient of variation. 
using different regions of Pinus oocarpa wood in the production of particleboard panels, which indicates that the residue generated in any radial position of Pinus oocarpa trees could be used in particleboard production with no damage to the physical properties.

Iwakiri et al. (2001) evaluated the potential use of five tropical pine species for production of particleboard panels with nominal density of $0.70 \mathrm{~g} / \mathrm{cm}^{3}$ and $8 \%$ of urea-formaldehyde adhesive. They found mean values for water absorption after two and 24 hours of immersion ranging from 68.80 to $83.60 \%$ and from 78.69 to $93.81 \%$, respectively. Regarding thickness swell, the mean values obtained after two and 24 hours of immersion ranged from 25.20 to $34.80 \%$ and from 32.70 to $39.70 \%$, respectively.

The CS 236 (CS, 1968) standard stipulates a maximum thickness swell value of $35 \%$ after 24 hours of immersion for particleboard panels of medium density and urea-formaldehyde adhesive. Thus, the results obtained for the physical properties of all treatments evaluated in this study were satisfactory according to the values found in the literature and were also in agreement with the requirements stipulated by the commercial standard.

\subsection{Mechanical properties}

With respect to the modulus of elasticity (MOE) (Table 5), the panels composed of wood from the internal region obtained the highest mean value, differing statistically from the other treatments, which were statistically equal. This result may be associated with the lower density of the internal region wood, which provided a higher compaction ratio to the panel (Table 3), and thus a better result for MOE.

As for the modulus of rupture (MOR) and internal bond properties (Table 5), no statistically significant difference was observed between the mixture and the internal and intermediate regions; these treatments presented the highest mean values for both properties. However, although the external region presented the lowest values of MOR and internal bond, no statistical difference was observed between this region and the mixture, which in general indicates that, as observed for the physical properties, any radial position of Pinus oocarpa trees could be used in the production of particleboard panels with no damage to the mechanical properties.

Table 4. Mean values of the physical properties of the panels.

\begin{tabular}{|c|c|c|c|c|}
\hline \multirow{2}{*}{ Treatment } & WA $2 \mathbf{h}$ & WA 24h & TS $2 \mathbf{h}$ & TS $24 \mathrm{~h}$ \\
\hline & \multicolumn{4}{|c|}{$\%$} \\
\hline External region & $83.5(3.3) \mathrm{B}$ & $94.7(5.4) \mathrm{B}$ & $25.4(8.5) \mathrm{B}$ & $29.0(8.4) \mathrm{B}$ \\
\hline Intermediate region & $81.3(5.9) \mathrm{B}$ & $95.9(4.5) \mathrm{B}$ & $22.6(26.5) \mathrm{B}$ & $27.0(23.5) \mathrm{B}$ \\
\hline Internal region & $24.5(28.2) \mathrm{A}$ & $47.1(1.7) \mathrm{A}$ & $9.1(15.0) \mathrm{A}$ & 16.9 (8.4)A \\
\hline Mixture & $79.1(5.5) \mathrm{B}$ & $93.2(1.9) \mathrm{B}$ & $21.8(40.4) \mathrm{B}$ & $26.3(12.4) \mathrm{B}$ \\
\hline${ }^{\star} \mathrm{CS} 236(\mathrm{CS}, 1968)$ & - & - & & 35.0 \\
\hline
\end{tabular}

Means followed by the same letter in the column do not differ statistically by the Tukey test at $5 \%$ significance level. The values in parentheses correspond to the coefficient of variation. WA $2 \mathrm{~h}=$ Water absorption after two hours of immersion; WA $24 \mathrm{~h}=$ Water absorption after 24 hours of immersion; TS $2 \mathrm{~h}=$ Thickness swell after two hours of immersion; TS $24 \mathrm{~h}=$ Thickness swell after 24 hours of immersion; ${ }^{*}$ Maximum stipulated by the CS 236 (CS, 1968) standard.

Table 5. Mean values of the mechanical properties of the panels.

\begin{tabular}{cccc}
\hline \multirow{2}{*}{ Treatment } & MOE & MOR & IB \\
\cline { 2 - 4 } & & $\mathbf{M P a}$ & $0.63(11.8) \mathrm{B}$ \\
\hline External region & $1978.18(1.9) \mathrm{B}$ & $9.47(5.3) \mathrm{B}$ & $1.05(9.1) \mathrm{A}$ \\
\hline Intermediate region & $2012.43(16.6) \mathrm{B}$ & $11.27(21.0) \mathrm{AB}$ & $0.96(4.1) \mathrm{A}$ \\
\hline Internal region & $2823.45(12.9) \mathrm{A}$ & $13.52(15.0) \mathrm{A}$ & $0.84(18.1) \mathrm{AB}$ \\
\hline Mixture & $2569.00(7.1) \mathrm{B}$ & $11.64(5.7) \mathrm{AB}$ & 0.41 \\
\hline${ }^{\star}$ CS 236 (CS, 1968) & 2402.63 & 10.98 & \\
\hline
\end{tabular}

Means followed by the same letter in the column do not differ statistically by the Tukey test at $5 \%$ significance level. The values in parentheses correspond to the coefficient of variation. $\mathrm{MOE}=$ Modulus of elasticity; MOR = Modulus of rupture; $\mathrm{IB}=$ Internal bond; $\mathrm{MPa}=$ specific pressure in megapascal; ${ }^{*}$ Minimum required by the CS 236 (CS, 1968) standard. 
Iwakiri et al. (2010) evaluated the quality of particleboard panels produced with a nominal density of $0.70 \mathrm{~g} / \mathrm{cm}^{3}, 8 \%$ of urea-formaldehyde adhesive, and the species Pinus caribaea var. Caribaeae and Pinus caribaea var. Bahamensis in different proportions. The authors obtained values ranging from 1886 to $2515 \mathrm{MPa}$ for MOE, from 12.03 to 18.08 MPa for MOR, and from 0.58 to $1.30 \mathrm{MPa}$ for internal bond. The CS 236 commercial standard (CS, 1968) stipulates minimum values of $2402.63 \mathrm{MPa}$ for MOE, $10.98 \mathrm{MPa}$ for MOR, and $0.41 \mathrm{MPa}$ for internal bond, considering medium density panels produced with urea-formaldehyde adhesive.

In this context, the mean values obtained for the mechanical properties were in agreement with those found in the literature. However, when compared to the standard, only the panels produced with the integral $\log$ (mixture) and with the internal region met all the requirements stipulated by the commercial standard. The external region did not reach the minimum requirements stipulated for MOE and MOR and the intermediate region did not reach the minimum requirements stipulated for MOE.

\section{CONCLUSION}

Wood radial position affected the quality of particleboard panels and a direct influence of the chemical composition and density of the material used was observed. Only panels produced with the integral $\log$ (mixture) and with the internal region met all the requirements stipulated by the commercial standard. Modifications in the production process adopted in this study are required for the separate use of the external and intermediate regions of the wood.

\section{ACKNOWLEDGEMENTS}

The authors thank the Fundação de Amparo à Pesquisa do Estado de Minas Gerais - FAPEMIG; Coordenacão de Aperfeiçoamento de Pessoa de Nível Superior - CAPES; Conselho Nacional de Desenvolvimento Científico e Tecnológico - CNPq; Embrapa Instrumentação; and PPGBiomat - Programa de Pós-Graduação em Engenharia de Biomateriais of the Federal University of Lavras.

\section{SUBMISSION STATUS}

Received: 3 oct., 2014

Accepted: 9 apr., 2017

\section{CORRESPONDENCE TO}

\section{Rafael Farinassi Mendes}

Department of Engineering, Universidade

Federal de Lavras - UFLA, Campus

Universitário, CP 3037, Lavras, MG, Brazil

e-mail: rafael.mendes@deg.ufla.br

\section{FINANCIAL SUPPORT}

Fundação de Amparo à Pesquisa do Estado de Minas Gerais - FAPEMIG, Conselho Nacional de Desenvolvimento Científico e Tecnológico - CNPq.

\section{REFERENCES}

American Society for Testing and Materials - ASTM. ASTM-D1037: standard methods of evaluating properties of wood-base fiber and particles materials. Philladelphia: ASTM; 2006.

Arantes MDC, Trugilho PF, Lima JT, Carneiro ACO, Alves E, Guerreiro MC. Longitudinal and radial variation of extractives and total lignin contents in a clone of Eucalyptus grandis W.Hill ex Maiden $\mathrm{x}$ Eucalyptus urophylla S. T. Blake. Cerne 2011; 17(3): 283-291. http://dx.doi.org/10.1590/ S0104-77602011000300001.

Associação Brasileira de Normas Técnicas - ABNT. NBR11941: madeira: determinação da densidade básica. Rio de Janeiro: ABNT; 2003a.

Associação Brasileira de Normas Técnicas - ABNT. NBR-13999: papel, cartão, pastas celulósicas e madeira: determinação do resíduo (cinza) após a incineração a 525 ${ }^{\circ} \mathrm{C}$. Rio de Janeiro: ABNT; 2003b.

Associação Brasileira de Normas Técnicas - ABNT. NBR-14810-3: chapas de madeira aglomerada: métodos de ensaio. Rio de Janeiro: ABNT; 2006.

Associação Brasileira de Normas Técnicas - ABNT. NBR-14853: madeira: determinação do material solúvel em etanol-tolueno e em diclorometano e em acetona. Rio de Janeiro: ABNT; 2010a.

Associação Brasileira de Normas Técnicas - ABNT. NBR-7989: pasta celulósica e madeira: determinação de lignina insolúvel em ácido. Rio de Janeiro: ABNT; 2010b.

Cabral CP, Vital BR, Lucia RMD, Pimenta AS. Propriedades de chapas de aglomerado confeccionadas com mistura de partículas de Eucalyptus spp and Pinus elliottii. Revista 
Árvore 2007; 31(5): 897-905. http://dx.doi.org/10.1590/ S0100-67622007000500014.

Commercial Standard - CS. CS 236-66: mat formed wood particleboard. Geneva: CS; 1968.

Dacosta LPE, Haselein CR, Santini EJ, Schneider PR, Calegari L. Qualidade das chapas de partículas aglomeradas fabricadas com resíduos do processamento mecânico da madeira de Pinus elliottii (Engelm.). Ciência Florestal 2005; 15(3): 311-312. http://dx.doi.org/10.5902/198050981869.

Deutsches Institut für Normung - DIN. DIN-52362: testing of wood chipboards bending test, determination of bending strength. Berlin: DIN; 1982.

Felix AL, Narciso CRP, Lima FS, Mendes RF, Mendes LM, Scolforo JRS. Use of waste wood for particleboard production. Key Engineering Materials 2016; 668(1):375-380.

Guimarães JB Jr, Mendes LM, Mendes RF, Mori FA. Painéis de madeira aglomerada de resíduos da laminação de diferentes procedências de Eucalyptus grandis, Eucalyptus saligna E Eucalyptus cloeziana. Cerne 2011; 17(4): 443-452. http://dx.doi.org/10.1590/S0104-77602011000400002.

Iwakiri S, Cruz CR, Brand MA. Utilização de resíduos de serraria na produção de chapas de madeira Aglomerada de Eucalyptus saligna, Eucalyptus citriodora e Eucalyptus pilularis. Floresta e Ambiente 2000; 7(1): 251-256.

Iwakiri S, Manhiça AA, Parchen CFA, Cit EJ, Trianoski R. Use of wood from Pinus caribaea var. caribaea and Pinus caribaea var. bahamensis for production of particleboard panels. Cerne 2010; 16(2): 193-198. http://dx.doi.org/10.1590/ S0104-77602010000200011.

Iwakiri S, Silva JRM, Matoski SLS, Leonhadt G. Produção de chapas de madeira aglomerada de cinco espécies de pinus tropicais. Floresta e Ambiente 2001; 8(1): 137-142.

Iwakiri S, Vianez BF, Weber C, Trianoski R, Almeida VC. Avaliação das propriedades de painéis aglomerados produzidos com resíduos de serrarias de nove espécies de madeiras tropicais da Amazônia. Acta Amazonica 2012; 42(1): 59-64. http://dx.doi.org/10.1590/S004459672012000100007.

Maloney TM. Modern particleboard and dry-process fiberboard manufacturing. 2nd ed. São Francisco: M. The Freeman; 1993.

Mendes RF, Mendes LM, Abranches RAS, Santos RC, Guimaraes JB Jr. Painéis aglomerados produzidos com bagaço de cana em associação com madeira de eucalipto. Scientia Forestalis 2010; 38(86): 285-295.

Morais SAL, Nascimento EA, Melo DC. Análise da madeira de Pinus oocarpa parte I: estudo dos constituintes macromoleculares e extrativos voláteis. Árvore 2005; 29(3): 461-470. http://dx.doi.org/10.1590/S010067622005000300014 .

Tsoumis G. Science and technology of wood: structure, properties, utilization. New York: Van Nostrand Reinhold; 1991. 
Floresta e Ambiente 2018; 25(1): e00250101

\section{Erratum}

In the article "Particleboard Panels Produced with Different Radial Positions of Pinus oocarpa Wood", DOI: http://dx.doi.org/10.1590/2179-8087.114514, published in Floresta e Ambiente, vol. 25, no.1, on the first page:

Where it reads:

Thiago de Paula Protássio

It should be read:

Thiago de Paula Protásio 